\author{
KONRAD LIPIŃSKI \\ ORCID: 0000-0001-5342-4905 \\ Uniwersytet Wrocławski \\ konrad.lipinski@uwr.edu.pl
}

\title{
O niektórych powiązaniach między ekspansywnością prawa karnego a państwową ingerencją w gospodarkę (perspektywa indywidualistyczna)
}

Słowa kluczowe: indywidualizm, kolektywizm, interwencjonizm gospodarczy, paternalizm.

Abstract

The article deals with the issue of common elements between expansion of criminal law regulations and state intervention in the economy. Taking the perspective of individualism, the author assumes that the paternalism behind these phenomena is difficult to accept. In a liberal state, the law should not be used to impose certain moral attitudes on citizens.

Keywords: individualism, collectivism, economic interventionism, paternalism.

Państwo jest naszym wrogiem, a podatki to zinstytucjonalizowana kradzież. Z takiego zapewne założenia wyszliby libertarianie, jeśliby ich spytać, do jakiego stopnia akceptowalne jest ,rozlewanie się” państwa na coraz to nowe dziedziny życia społecznego ${ }^{1}$, stanowiące wszak z konieczności ingerencję w autono-

1 Zob. A.J. Nock, Państwo — nasz wróg, przeł. L.S. Kołek, Warszawa-Lublin 2017, passim; M.N. Rothbard, Manifest libertariański, przeł. W. Falkowski, Warszawa 2014, s. 26, 49 n. Postrzegając zaś to zagadnienie z drugiej strony, Murray Rothbard wskazywał, że „w pewnym sensie cały 
mię jednostki. W literaturze odwołującej się do indywidualizmu bodaj najszerzej omówiono zaś przyczyny, charakterystykę i konsekwencje (nadmiernego) zaangażowania państwa w swobody ekonomiczne jednostki. Również z perspektywy indywidualistycznej, i to niekoniecznie odwołując się do poglądów, które można by uznać za skrajne (czy jednak pojęciowo możliwa jest inna postać wolności niż „skrajna”?), dostrzec można pewną — być może na pierwszy rzut oka trudną do uchwycenia - zależność między zbyt szerokim posługiwaniem się przez ustawodawcę prawem karnym oraz państwową ingerencją w gospodarkę. Powiązanie to przejawia się przede wszystkim na dwu płaszczyznach.

Po pierwsze, zarówno interwencjonizm gospodarczy, jak i nadmierna represyjność prawa karnego wiążą się z naruszeniem wolności jednostki, choć w dużej mierze w odmiennych aspektach. Nie trzeba uciekać się do określeń nacechowanych pejoratywnie (takich jak wspomniany ,wróg” czy „,agresor”), aby dostrzec, że immanentną, sygnalizowaną już właściwością państwa jest ograniczanie wolności obywateli. Można oczywiście twierdzić, że cecha ta jest nieodzowna dla realizacji słusznych celów, bądź że ponoszony w tym układzie „koszt” jest niższy od otrzymywanego „zysku” w postaci bezpieczeństwa lub rożnego rodzaju usług publicznych, lecz sam fakt nastawania przez państwo na wolność zdaje się niemożliwy do zakwestionowania. Podobieństwo polega zatem na wspólnej idei stojącej za interwencją w stosunki gospodarcze oraz ingerowaniem w wolność jednostki za pomocą norm sankcjonowanych, które następnie obwarowywane są najpoważniejszym instrumentarium, jakie państwo posiada w sferze stanowienia prawa — jego legislacyjnym „zbrojnym ramieniem”, jakim jest prawo karne. Ideą tą jest zagwarantowanie przez państwo czy rząd ${ }^{2}$ bezpieczeństwa tudzież sprawiedliwości, niekiedy okraszanej — jak chociażby w art. 2 Konstytucji Rzeczpospolitej Polskiej — dodatkowym określeniem „społeczna”3.

Po drugie, stopień państwowej ingerencji w gospodarkę, podobnie jak sposób i zakres posługiwania się przez państwo prawem karnym, stanowi swoisty papierek lakmusowy panującego systemu politycznego. W przypadku zagadnień ekonomicznych dzieje się tak dlatego, że — starając się syntetycznie oddać za-

system podatkowy ma charakter niewolniczy. W szczególności gdy weźmiemy pod uwagę podatek dochodowy, to widzimy, że jego wysokie stawki zmuszają obywateli do pracy przez dużą część roku — kilka miesięcy — za darmo, dla Wujka Sama [...]. Podatek dochodowy oznacza właśnie, że pracujemy w pocie czoła, by uzyskać dochód, którego dużą część rząd zabierze nam pod przymusem na własne potrzeby. Czymże to jest, jeśli nie przymusową pracą bez wynagrodzenia?”ibidem, s. 92.

${ }^{2} \mathrm{~W}$ anglojęzycznej literaturze dotyczącej relacji jednostki z państwem zarówno rząd, jak i państwo określane są szerokim pojęciem government, co niekiedy może być mylące. Por. A.J. Nock, op. cit., s. 31 n.; H.D. Thoreau, O obywatelskim niepostuszeństwie, przeł. M. Barski, Warszawa 2020, s. 1.

3 W zakresie krytyki sprawiedliwości „społecznej” ze wspomnianej na wstępie opracowania perspektywy zob. F.A. von Hayek, Prawo, legislacja $i$ wolność, przeł. G. Łuczkiewicz, Warszawa 2020, s. $291 \mathrm{n}$. 
sadniczą myśl Drogi do zniewolenia Friedricha Augusta von Hayeka — odebranie człowiekowi możliwości decydowania o sposobie wykorzystania uzyskanego dochodu (wiązane w szerszej perspektywie z planowaniem gospodarczym) z konieczności prowadzić musi do ograniczenia wolności w innych sferach jego życia. Jest to konsekwencja spostrzeżenia, zgodnie z którym:

poczucie bezpieczeństwa, które ludzie wywodzą z owej wiary, że władza sprawowana nad naszym życiem gospodarczym rozciąga swe panowanie na sprawy o drugorzędnym znaczeniu, jest całkowicie nieusprawiedliwione. Jest to w dużym stopniu konsekwencja błędnego przekonania, że istnieją cele czysto ekonomiczne, które nie wiążą się z pozostałymi celami życiowymi [...]. Podstawowe cele działalności istot rozumnych nigdy nie mają charakteru ekonomicznego. Mówiąc wprost, nie istnieje „motywacja ekonomiczna”, lecz tylko czynniki ekonomiczne warunkujące nasze dążenia do innego rodzaju celów. To, co w potocznym języku bałamutnie nazywa się ,motywacją ekonomiczną”, oznacza po prostu pragnienie uzyskania ogólnych możliwości, chęć osiągnięcia możliwości urzeczywistniania nieokreślonych jeszcze celów ${ }^{4}$.

Nieco spłaszczając omawiane tu zagadnienie, można zatem stwierdzić, że wolność ekonomiczna otwiera możliwości na innych niż czysto gospodarczy frontach, a skoro tak, to ograniczenie tej pierwszej nieuchronnie wiązać się musi z ograniczeniem innych „kategorii” wolności.

Prawo karne staje się natomiast papierkiem lakmusowym systemu politycznego państwa $z$ tego względu, że spełnia dwie zasadnicze funkcje, które powinny pozostawać we wzajemnej równowadze: ochronną i gwarancyjną. Pierwsza z nich odnosi się do ochrony społeczeństwa, druga zaś gwarantuje jednostce ochronę przed nieuprawnionym i zbyt intensywnym wkraczaniem (w najbardziej drastyczny wszak sposób) w wolność człowieka wszędzie tam, gdzie nie jest to absolutnie niezbędne. Nawiązanie do równowagi między interesem jednostkowym a interesem zbiorowości (kolektywnym), legitymizującym państwową interwencję w gospodarkę, jest tu zatem dość łatwe do uchwycenia. Nadto, jeśli chodzi o zagadnienia ściśle prawnokarne, przytoczyć należy za Andrzejem Zollem, że w systemie państwa prawa szanującego autonomię jednostki „na plan pierwszy wysuwa się spowodowanie czynem zagrożenia dla dobra albo uszczerbku dla dobra. Aspekt nieposłuszeństwa wobec polecenia władzy nie jest pomijany, ale schodzi zdecydowanie na dalszy plan", podczas gdy w systemie — ujmijmy problem delikatnie oddalającym się od tego ideału, ,przestępstwo jest przede wszystkim naruszeniem obowiązku posłuszeństwa wobec władzy. O przestępności czynu decyduje więc w pierwszym rzędzie ocena etyczna czynu"5. Również zresztą w zakresie zagadnienia regulowania moralności przez prawo jako probierza systemu politycznego państwa odnaleźć można adekwatną wypowiedź von Hayeka:

${ }^{4}$ F.A. von Hayek, Droga do zniewolenia, przeł. K. Gurba et al., Kraków 2015, s. 104. Podobną myśl znajdziemy w: L. von Mises, Planowany chaos, przeł. L.S. Kołek, Warszawa 2019, s. 28 n.

5 A. Zoll, Prawo karne w systemie totalitarnym, „Znak” 1992, nr 11, s. 115. 
Państwo przestaje być jednym z użytecznych mechanizmów, który ma pomagać jednostkom w jak najpełniejszym rozwoju ich osobowości, a staje się instytucją „moralną” — przy czym słowo „moralna” nie zostało tu użyte jako przeciwieństwo terminu „,niemoralna”, lecz charakteryzuje ono instytucję, która narzuca swym członkom własne poglądy na wszelkie kwestie moralne, czy też wysoce niemoralne. W tym sensie [...] państwo kolektywistyczne jest „moralne”, natomiast państwo liberalne nie ${ }^{6}$.

W dalszej części opracowania postaram się możliwie zwięźle wskazać już to zagadnienia, w ramach których da się wysnuć analogię między potencjalnie oceniając z zarysowanej na wstępie perspektywy — zbyt daleko idącą ingerencją państwa w prawa i wolności w sferach ekonomicznej oraz prawnokarnej, już to kwestie, w których oba rodzaje ingerencji „idą pod rękę”. Może się bowiem zdarzyć tak — choć jest to stan rzeczy niewątpliwie niepożądany ${ }^{7}$ — że prawodawca zdecyduje się ingerować w życie i wybory obywateli, posługując się prawem karnym jako regulatorem życia społecznego. Takiego stanu rzeczy niepodobna jednak akceptować $\mathrm{z}$ tego względu, że prawo karne powinno być w państwie szanującym wolność swych obywateli postrzegane jako ostateczność (ultima ratio), a zatem instrument, do którego sięgać wolno jedynie wówczas, gdy inne rodzaje regulacji nie są wystarczające. Prawo karne pełnić bowiem powinno funkcję subsydiarną, zabezpieczając jedynie to, co pierwotnie regulowane jest przez inne gałęzie prawa ${ }^{8}$. Używając zgrabnego określenia Tomasza Kaczmarka, modelowo rzecz ujmując, stanowi ono „swoisty aneks do pozostałych dziedzin prawa obowiązującego"9.

Przyjrzyjmy się zatem kilku prawnokarnym regulacjom, które z perspektywy indywidualistycznej mogłyby zostać uznane za ingerujące w wolność zbyt głęboko, a być może nawet w stopniu, który — szczególnie u zwolennika myśli libertariańskiej — mógłby wywołać pewne zaniepokojenie. Nasuwają się trzy przykłady, które można by przyporządkować do trzech sfer aktywności ludzkiej. Pierwszym z nich będzie kryminalizacja posiadania środków odurzających na własny użytek; drugim sankcjonowanie, oczywiście przy spełnieniu pewnych dodatkowych warunków, dobrowolnych stosunków seksualnych między osobami zdolnymi do autodeterminacji seksualnej; trzecim zaś prawnokarne „zabezpieczanie” państwo-

${ }^{6}$ F. A. von Hayek, Droga..., s. 91.

7 W systemach prowolnościowych nie powinno się wszak regulować prawnie stosunków społecznych, sięgając od razu po takie instrumentarium, które ingeruje w prawa i wolności w najintensywniejszy możliwy sposób. Dlatego właśnie zasadniczo prawo karne nie pełni funkcji porządkującej czy organizującej porządek prawny. Zob. A. Zoll, O normie prawnej z punktu widzenia prawa karnego, „Krakowskie Studia Prawnicze” 1990, nr 23, s. 72.

8 Zob. między innymi A. Zoll, Karalność i karygodność jako odrębne elementy struktury przestępstwa, [w:] Teoretyczne problemy odpowiedzialności karnej w polskim oraz niemieckim prawie karnym, red. T. Kaczmarek, Wrocław 1990, s. 102-103.

9 T. Kaczmarek, Recenzja pracy R. Dębskiego: „Pozaustawowe znamiona przestęstwa (O ustawowym charakterze norm prawa karnego i znamionach typu czynu zabronionego nie określonych w ustawie)”, „Państwo i Prawo” 1996, nr 8, s. 133-134. 
wej interwencji w gospodarkę poprzez kryminalizację łamania zakazu handlu w niedziele oraz zniechęcania do udziału w pracowniczych planach kapitałowych.

Aktualny model odpowiedzialności karnej za przestępstwa narkotykowe, stanowiący przejaw podejścia prohibicyjnego, można krytykować z wielu perspektyw ${ }^{10}$. Zasadniczy jednak problem $\mathrm{w}$ kontekście wkraczania państwa w prawa i wolności jednostki wiąże się z tym, że w obowiązującym ujęciu normatywnym czyn zabroniony stanowi posiadanie również nieznacznej ilości środków odurzających lub substancji psychotropowych, przeznaczonych na użytek samego posiadacza ${ }^{11}$. W sposób naturalny pojawić się musi zatem pytanie, czy tego rodzaju ograniczenie wolności, stanowiące przejaw ingerencji w prywatność jednostek oraz ich prawo do decydowania o własnym zdrowiu i życiu, dałoby się z jakichś względów uznać za usprawiedliwione. Spoglądając na zagadnienie z perspektywy indywidualistycznej, w szczególności zaś libertariańskiej, niechybnie należałoby udzielić odpowiedzi przeczącej. Groźba wymierzenia kary (pozbawienia wolności, ograniczenia wolności czy zaboru mienia w postaci grzywny) wiązana nie z naruszaniem cudzych dóbr, a jedynie „zewnętrznie” krytykowanym sposobem dysponowania własną wolnością, musiałaby bowiem być postrzegana jako przykład agresji, sprzecznej z zasadniczym założeniem libertarianizmu ${ }^{12}$. Rzecz bowiem w tym, że kryminalizację posiadania środków odurzających na własny użytek legitymizuje się między innymi odwołaniem do takich wartości, jak ,zdrowie publiczne" czy bardziej jeszcze nieuchwytny $\mathrm{i}$ - jak z pewnością stwierdziliby skrajni indywidualiści - pozbawiony treści „porządek publiczny”13. Pod tym właśnie płaszczykiem władza państwowa rości sobie prawo do decydowa-

${ }^{10}$ Zob. K. Krajewski, Sens i bezsens prohibicji. Prawo karne wobec narkotyków i narkomanii, Kraków 2001, s. 81 n.

$11 \mathrm{~W}$ art. 62a ustawy z 29 lipca 2005 roku o przeciwdziałaniu narkomanii (Dz.U. z 2020 r. poz. 2050) przewidziano co prawda możliwość umorzenia postępowania, otwierającą się, jeśli przedmiotem czynu są środki odurzające lub substancje psychotropowe w ilości nieznacznej, przeznaczone na własny użytek sprawcy, wszelako przepis ten naszpikowany jest klauzulami generalnymi, zaś jego zastosowanie jest fakultatywne, a obserwując praktykę wymiaru sprawiedliwości, trudno się oprzeć wrażeniu, że również wybiórcze. Umieszczenie tego rodzaju instytucji w ustawie nie zmienia przy tym zasadniczego faktu (a wręcz stanowi jego potwierdzenie), że posiadanie nieznacznej ilości środka odurzającego na własny użytek pozostaje czynem bezprawnym i karalnym, w przypadku którego niekiedy jedynie na zasadzie wyjątku można odstąpić od ścigania sprawcy. Por. A. Muszyńska, Uwagi na temat uwarunkowań polityki karnej realizowanej przez sądy na przykładzie stosowania art. 178 a $\$ 2$ k.k. i art. 62-62a ustawy z 2005 roku o przeciwdziataniu narkomanii, „Nowa Kodyfikacja Prawa Karnego” 57, 2020, s. 28-29.

12 Omawiając aksjomat nieagresji („,centralny pewnik” libertariańskiego credo), Murray Rothbard zauważył, że „,»agresję« definiuje się jako zainicjowanie użycia lub groźbę użycia fizycznej przemocy przeciwko osobie lub własności innego człowieka. Jeśli nikt nie ma prawa posuwać się do agresji, czyli jeśli każdy ma niepodważalne prawo do »wolności« od agresji, to tym samym libertarianin opowiada się kategorycznie za prawami powszechnie znanymi jako »swobody obywatelskie «" - zob. idem, op. cit., s. 25.

13 Por. wyrok Trybunału Konstytucyjnego z 4 listopada 2014 roku, sygn. SK 55/13, OTK-A 2014, nr 10, poz. 111. 
nia o tym, co dla obywateli jest najbardziej odpowiednie ${ }^{14}$. Jest to zatem przejaw państwowego paternalizmu, który można zdefiniować jako „narzucanie określonej hierarchii dóbr wartości prawem chronionych, niezależnie od rzeczywistych preferencji dysponenta danego dobra"15. Patrząc na problem z perspektywy indywidualistycznej, można jednak sformułować przynajmniej dwa zastrzeżenia. Po pierwsze, nasuwa się dość dobrze uzasadnione pytanie, czy ontologicznie rzecz ujmując, coś takiego jak ,publiczne” zdrowie w ogóle istnieje, a zatem, czy zdrowie przysługiwać może komukolwiek innemu niż pojedynczy człowiek ${ }^{16}$. Po drugie, na tle omawianego zagadnienia z pełną mocą ujawnia się — jak zapewne stwierdziłby libertarianin - swoista manipulacja polegająca na kreowaniu przez ustawodawcę dóbr prawnych o charakterze ponadindywidualnym ${ }^{17}$, stanowiąca próbę ukrycia tego, że w istocie tego rodzaju zachowaniem nikt (poza samym sprawcą) nie jest pokrzywdzony, zaś wkroczenie w prawa i wolności obywatelskie nie ma odpowiedniego uzasadnienia ${ }^{18}$. Zwolennicy kryminalizacji posiadania środków odurzających mogliby natomiast, „odbijając piłeczkę”, posłużyć się argumentem odwołującym się do kosztów leczenia uzależnienia od narkotyków ${ }^{19}$. Słysząc taki argument, libertarianin jednak z pewnością jedynie zatarłby ręce, wskazując, że „wpuszczenie" państwa do jednej sfery życia nieodzownie prowadzi do zawłaszczania wolności (a zatem — w libertariańskiej nomenklaturze — do agresji) na coraz to nowych polach. Wszak teza o społecznych kosztach leczenia uzależnionych nie miałaby najmniejszego sensu wówczas, gdyby ponosili je oni sami, a nie ogół społeczeństwa na skutek ,upublicznienia” służby zdrowia. Mówiąc inaczej, jeśliby państwo pierwotnie nie ingerowało w stosunki gospodarcze poprzez wyłączenie spod reguł rynkowych służby zdrowia (a dokładniej: objęcie społeczeństwa obowiązkiem regularnego uiszczania składki zdrowotnej), problem ,społeczne-

14 M. Klinowski, Ustawa o przeciwdziałaniu narkomanii a konstytucyjna zasada proporcjonalności, „Prokuratura i Prawo” 2009, nr 2, s. 76.

15 M. Budyn, Kryminalizacja eutanazji, posiadania narkotyków oraz eksploatacji prostytucji - przejawy usprawiedliwionego paternalizmu państwa?, „Annales Universitatis Mariae Curie-Skłodowska - Sectio G” 49, 2002, s. 127.

16 Wydaje się zresztą, że posługiwanie się takimi właśnie określeniami jak ,zdrowie publiczne" stanowi doskonały przykład zagadnienia redukcji indywidualizującej (tudzież jej odwrotności). Zob. S. Czepita, Czesława Znamierowskiego koncepcja „,redukcji indywidualizujacej”, „Ruch Prawniczy, Ekonomiczny i Socjologiczny" 1987, nr 3, s. 63.

$17 \mathrm{~W}$ pewnym ujęciu można by je chyba utożsamić z dobrami instrumentalnymi. Zob. S. Tarapata, Dobro prawne w strukturze przestępstwa. Analiza teoretyczna i dogmatyczna, Warszawa 2016, s. 100-107.

${ }^{18}$ Zob. interesujące rozważania Dagmary Gruszeckiej na temat wszelakich zabiegów, jakimi posługuje się ustawodawca, rozszerzając kryminalizację na zachowania znajdujące się na przedpolu naruszenia dobra prawnego - eadem, Ochrona dobra prawnego na przedpolu jego naruszenia. Analiza karnistyczna, Warszawa 2012, s. 207 n.

19 Zob. M. Derlatka, Konstytucyjność kryminalizacji posiadania narkotyków, „Prokuratura i Prawo" 2010, nr 7-8, s. 91. 
go kosztu" narkomanii - przynajmniej rozumianego w sposób czysto materialny - nie powstałby ${ }^{20}$.

Z drugiej zaś strony, tytułowe powiązanie między państwową ingerencją w gospodarkę a regulowaniem stosunków społecznych przez prawo karne jest w tym przypadku wyjątkowo łatwe do uchwycenia, a wręcz namacalne. Przyjmując zaproponowaną na wstępie perspektywę, bez większych problemów stwierdzilibyśmy, że to właśnie państwowy interwencjonizm czyni ze zdrowia poszczególnych jednostek kwestię publiczną, legitymizując na dalszym etapie ich karanie za wykroczenie przeciwko wykreowanemu w ten sposób ,publicznemu” dobru, tworząc swego rodzaju antyindywidualistyczną ,samospełniającą się przepowiednię”. Doskonałą antytezą wcześniej przy toczonej wypowiedzi F.A. von Hayeka, zgodnie z którą państwo liberalne musi być amoralne, może być natomiast odnosząca się do kryminalizacji posiadania narkotyków wypowiedź Marka Derlatki: „Więzienie nie służy terapii narkomanów, jednak zagrożenie karą pozbawienia wolności powinno pomagać $\mathrm{w}$ internalizacji norm nie tylko prawnych, ale również etycznych, zdecydowanie potępiających zażywanie narkotyków. [...] Prawo karne jest instrumentem kształtowania właściwych postaw społecznych, wśród nich mieści się zapewne wolność od nałogu narkotykowego"21.

Indywidualizm z założenia sprzeciwia się penalizacji zachowań, które nie godzą w prawa jednostki, a zatem w jaskrawej opozycji do jego założeń stoi objęcie sankcją karną czynów, które w skrócie nazywa się przestępstwami bez ofiar ${ }^{22}$. Państwowa interwencja ze względów etycznych czy moralnych — podobnie jak ma to miejsce w przypadku ingerencji w zasady wolnego rynku — przejawia się jednak w szeregu przepisów aktualnie obowiązującego kodeksu karnego, w tym nawet $\mathrm{w}$ rozdziale XXV, grupującym przestępstwa przeciwko wolności seksualnej i obyczajności ${ }^{23}$. Posłużmy się w tym zakresie dwoma przykładami: kryminalizacją kazirodztwa oraz eksploatacji prostytucji.

20 Trudno w tym kontekście nie zgodzić się ze spostrzeżeniem M.N. Rothbarda (skądinąd inspirowanym wypowiedziami Ludwiga von Misesa), sformułowanym właśnie na marginesie zagadnienia szeroko rozumianej publicznej służby zdrowia: „Państwo w swej mądrości spostrzega problem (i na Boga, problemy znajdą się zawsze!). Następnie dokonuje interwencji, by ten problem »rozwiązać«. Ale — cóż za niespodzianka! — zamiast rozwiązywać pierwotny problem, interwencja rodzi dwa lub trzy kolejne” — idem, Rzadowe ,ubezpieczenie” medyczne, [w:] Ekonomiczny punkt widzenia, przeł. J. Lewiński, M. Zieliński, Wrocław 2015, s. 66.

21 M. Derlatka, op. cit. s. 90.

${ }^{22}$ Konkretniej rzecz ujmując, zachowań takich „libertarianin w ogóle nie uważa za »przestępstwa«, gdyż pod pojęciem »przestępstwa« rozumie brutalne naruszenie czyjejś nietykalności osobistej lub własności" - M.N. Rothbard, op. cit., s. 25; zob. też R. Nozick, Anarchia, państwo i utopia, przeł. P. Maciejko, M. Szczubiałka, Warszawa 2010, s. 51 n.; L. Falandysz, O koncepcji tzw. „przestępstw bez ofiar”, „Państwo i Prawo” 1978, nr 7-8, s. 107-108.

${ }^{23}$ Zaznaczmy jednak lojalnie, że dalej omawiane przykłady przestępstw za swój przedmiot ochrony biorą - w moim przekonaniu — obyczajność, a nie wolność seksualną (zob. K. Lipiński, [w:] Kodeks karny. Część szczególna. Komentarz, red. J. Giezek, Warszawa 2021, s. 660 i 681), choć nie jest to pogląd jednolicie przyjmowany w doktrynie. Zarazem jednak uczynienie z obyczajno- 
Za kryminalizacją kazirodztwa przemawia niewątpliwie i niezaprzeczalnie wyjątkowo jednoznacznie sformułowana norma moralna. Ujęcie w kodeksie karnym przestępstwa polegającego na dobrowolnym obcowaniu płciowym dwu osób pozostających względem siebie w bliskiej relacji ma jednak zarówno przeciwników $^{24}$, jak i gorących zwolenników ${ }^{25}$. Z perspektywy indywidualistycznej jego kryminalizacja za pomocą najpoważniejszego instrumentarium wkraczania w wolności obywatelskie musi się okazać przynajmniej wątpliwa, szczególnie jeśli wziąć pod uwagę, że nie dowiedziono istnienia zagrożeń eugenicznych wiążących się ze stosunkami kazirodczymi ${ }^{26}$. Trzeba sobie również zdawać sprawę z tego, że decydując się na kryminalizację tego rodzaju zachowań, ustawodawca uznaje niesmak i zgorszenie związane z naruszeniem norm obyczajowych leżących u podstaw zakazu obcowania płciowego osób pozostających ze sobą w relacjach rodzinnych za wystarczającą podstawę do ograniczenia wolności (obwarowanego sankcją karną) jednostek, które stosunki tego rodzaju chciałyby utrzymywać ${ }^{27}$. Nawet jednak porzucając perspektywę indywidualizmu, nasuwać się musi pytanie, czy ponadindywidualne dobro prawne w postaci obyczajności staje się naruszone lub dostatecznie istotnie zagrożone wówczas, gdy osoby pozostające ze sobą w relacji, jakiej wymaga art. 201 k.k., będąc zdolnymi do świadomej autodeterminacji seksualnej, dopuszczają się obcowania płciowego w zaciszu domowym, nie wywołując przy tym żadnego skonkretyzowanego niesmaku czy wstrętu u innych osób, poza ogólną — w żaden wszak sposób niezmienioną tym konkretnym przypadkiem świadomością, że niektórzy ludzie dopuszczają się takich czynów ${ }^{28}$.

Jak jednak wspomniano, w przypadku kazirodztwa norma moralna kryjąca się za wprowadzeniem powszechnie obowiązującego zakazu jest szczególnie ostro zarysowana (co skądinąd samo w sobie nie musi wszak uzasadniać prawnokarnej interwencji ${ }^{29}$ ). Racje o charakterze moralnym (czy może emocjonalnym) okazują

ści - a zatem dobra o charakterze ponadindywidualnym — przedmiotu prawnokarnej ochrony powoduje, że irrelewantna staje się zgoda osób realizujących znamiona czynu zabronionego.

24 J. Warylewski, [w:] Kodeks karny. Komentarz, red. R.A. Stefański, Warszawa 2020, art. 201, nb 13; K. Banasik, W kwestii penalizacji kazirodztwa, „Prokuratura i Prawo” 2011, nr 4, s. 70.

25 V. Konarska-Wrzosek, Przedmiot ochrony przy typie przestępstwa kazirodztwa, [w:] Aktualne problemy prawa karnego. Ksiega pamiatkowa z okazji jubileuszu 70. urodzin Profesora Andrzeja J. Szwarca, red. Ł. Pohl, Poznań 2009, s. 290-291.

26 A. Zoll, Ochrona prywatności w prawie karnym, „Czasopismo Prawa Karnego i Nauk Penalnych” 2000, nr 1, s. 225. Autor zwrócił przy tym uwagę, że art. 201 k.k. obejmuje również dobrowolne stosunki seksualne między przysposabiającym i przysposabianym.

27 J. Giezek, Kolizja dóbr a prawnokarna ochrona wolności, [w:] Prawnokarne aspekty wolności. Materiały z konferencji, Arłamów, 16-18 maja 2005 r., red. M. Mozgawa, Warszawa 2006, s. 86 .

28 Por. M. Budyn-Kulik, Prawnokarna problematyka kazirodztwa w ujęciu paternalistycznym, „Wojskowy Przegląd Prawniczy” 2012, nr 1-2, s. 70-71.

${ }_{29}$ Ustawodawca nie zdecydował się wszak na przykład na kryminalizację zdrady małżeńskiej, mimo niewątpliwie negatywnej oceny moralnej takich zachowań obowiązującej w społeczeństwie. 
się jednak zdecydowanie mniej intensywne w przypadku prostytucji, tym bardziej że przecież samo świadczenie usług seksualnych nie stanowi szczególnego przedmiotu zainteresowania prawa karnego. Ustawodawca zdecydował się jednak na penalizację takich zachowań jak podjęte w celu osiągnięcia korzyści majątkowej nakłanianie innej osoby do uprawiania prostytucji, ułatwianie tego procederu lub czerpanie z niego korzyści. Biorąc pod uwagę, że żadne z zachowań wymienionych w art. 204 § 1 i 2 k.k. nie wiąże się z wkroczeniem w autonomię osoby trudniącej się prostytucją, decyzja ustawodawcy — w istocie pośrednio, z perspektywy paternalistycznej, potępiającego samo to zjawisko - musi być uznana nie tylko za nieuzasadnioną, ale również niekonsekwentną ${ }^{30}$. Jest to zatem kolejny przykład, w którym państwo stosuje agresję (we wcześniej wskazanym ujęciu), w istocie ingerując $\mathrm{w}$ najbardziej bodaj prywatną sferę życia człowieka celem narzucenia określonego standardu moralnego. Biorąc pod uwagę, że dopuszczenie się tego rodzaju przestępstwa nie wiąże się z jakimkolwiek naruszeniem praw jednostki (nie czyni nikogo pokrzywdzonym), taki przejaw paternalizmu $-\mathrm{z}$ indywidualistycznego punktu widzenia - musi zostać uznany za nie tylko nieuzasadniony, ale również, być może paradoksalnie, moralnie naganny.

Całkowicie jawne powiązanie prawa karnego $\mathrm{z}$ ingerencją państwa w gospodarkę, a wręcz z jego finansowym interesem, przejawia się natomiast wszędzie tam, gdzie państwo (antropomorfizowane jako ustawodawca) postanawia zabezpieczyć prawnokarnymi normami sankcjonującymi porządek prawny w zakresie niepodporządkowania się jego zamysłom dotyczącym najprzeróżniejszych form regulacji rynku. Sferę oczywistą i najrozleglejszą stanowi tu oczywiście spora część prawa karnego skarbowego, niechybnie trudnego do legitymizacji szczególnie z perspektywy libertariańskiej (choćby w zakresie przestępstw i wykroczeń skarbowych przeciwko organizacji gier hazardowych). Równie reprezentatywnymi przykładami wyraźnego sympatyzowania ingerencji w sferę wolności ekonomicznej czy gospodarczej z groźbą wkroczenia w wolności jednostki za pomocą aparatury prawnokarnej są jednak nowsze pomysły legislacyjne, takie jak - posługując się pewnym uproszczeniem — zakaz handlu w niedziele oraz organizacja pracowniczych planów kapitałowych.

Poczynając przeto od pierwszej regulacji, w ramach której ograniczenie wolności gospodarczej idzie pod rękę z groźbą zastosowania zinstytucjonalizowanej przemocy w postaci sankcji karnej, należy odwołać się do art. 5 ustawy z 10 stycznia 2018 roku o ograniczeniu handlu w niedziele i święta oraz w niektóre inne $\mathrm{dni}^{31}$, a zatem przepisu zrębowego, z którego wyprowadzić można normę sankcjonowaną zakazującą handlu, wykonywania czynności związanych $\mathrm{z}$ handlem oraz powierzania takich czynności pracownikowi w niedziele i święta. $Z$ zakazem tym skoordynowano normy sankcjonujące wysłowione zarówno w art. 11 tej ustawy

${ }^{30}$ Zob. M. Budyn, Kryminalizacja..., s. 141.

31 Dz.U. z 2021 r. poz. 936. 
(wykroczenie), jak i w art. 218a k.k. (przestępstwo). Widać zatem, że przekonanie ustawodawcy o tym, że lepiej będzie, jeśli handel w niedziele i święta zostanie zakazany, jest na tyle głębokie, że postanowił zabezpieczyć je najpoważniejszym co do rodzajowego ciężaru gatunkowego - instrumentem, jakim tylko dysponuje.

Nie inaczej rzecz się przedstawia w przypadku pracowniczych planów kapitałowych, przy czym zbiegają się tu oba wcześniej omawiane problemy. Otóż zasadniczo — zgodnie z art. 23 ust. 1 ustawy z dnia 4 października 2018 roku o pracowniczych planach kapitałowych ${ }^{32}$ — przewiduje się, że „uczestnictwo w PPK jest dobrowolne", wszelako nie stanowi to dla ustawodawcy większej przeszkody, aby w art. 108 tejże ustawy przewidzieć typ czynu zabronionego polegający na nakłanianiu osoby zatrudnionej lub uczestnika PPK do rezygnacji z oszczędzania w pracowniczych planach kapitałowych. Podobnie jak w przypadku nakłaniania do uprawiania prostytucji, nie mamy tu przecież do czynienia $\mathrm{z}$ jakimkolwiek naruszeniem autonomii decyzyjnej innego człowieka ${ }^{33}$, jednak ustawodawca pośrednio i niekonsekwentnie - dał wyraz woli, aby do pracowniczych planów kapitałowych przystępowało jak najwięcej pracowników. Można jedynie domniemywać, że dodatkowy motyw stanowić mógł interes fiskalny państwa. Niezależnie jednak od tego, nie powinno budzić większych wątpliwości, że z perspektywy indywidualistycznej wkraczanie $\mathrm{z}$ instrumentarium prawnokarnym wobec braku naruszenia autonomii decyzyjnej czy innej sfery wolności człowieka musiałoby zostać uznane za niedopuszczalne.

Jest oczywiste, że sam fakt posługiwania się przez ustawodawcę prawem karnym wiązać się musi z ograniczeniem wolności człowieka. Przyjęcie pewnej perspektywy, szanującej prawa jednostki, pozwala na uzyskanie równowagi między tym, co w teorii prawa karnego określa się jego funkcją gwarancyjną (wiązaną $\mathrm{z}$ interesem jednostki), a tym, co odpowiada jego funkcji ochronnej (wiązanej z interesem zbiorowości). Są bowiem takie prawa jednostki, które nie powinny ustępować zbiorowości ${ }^{34}$. Przyjęcie punktu widzenia charakterystycznego dla indywidualizmu nakazuje relatywnie szeroko zakreślić katalog spraw, w które państwo nie powinno ingerować za pomocą regulacji prawnej. Perspektywa ta pozwala również założyć, że państwowy paternalizm, rozumiany jako narzucanie określonej hierarchii wartości dóbr — niezależnie od woli ich dysponentów — jest naganny moralnie, bowiem nie uwzględnia prawa jednostki do kontrolowania swego życia, $i$ to $w$ coraz szerszym zakresie ${ }^{35}$. Ów paternalizm jest zasadniczym elementem wspólnym, który stoi z jednej strony za państwową interwencją w gospodarkę, $\mathrm{z}$ drugiej zaś za prawnokarną ingerencją w wolność jednostki $\mathrm{w}$ dysponowaniu własnymi dobrami. Występujące między tymi zjawiskami powiązanie daje się do-

32 Dz.U. z 2020 r. poz. 1342.

33 Zob. jednak M. Derek, Nakłanianie do rezygnacji z oszczędzania w pracowniczych planach kapitatowych - analiza karnoprawna, „Palestra” 2018, nr 12, s. 7 n.

34 Zob. A. Zoll, Prawo..., s. 112-113.

35 M. Budyn, Kryminalizacja..., s. 127. 
strzec w dwóch zagadnieniach. Po pierwsze, polega ono na tym, że ograniczanie wolności ekonomicznej - jak zauważał F.A. von Hayek — nieodzownie wiązać musi się z ograniczeniem wolności człowieka $w$ innych sferach życia. Po drugie zaś, powiązanie to przejawia się w mechanizmie sankcjonowania przepisami prawa karnego naruszenia przez obywatela norm, które ustawodawca ustanowił, wkraczając $\mathrm{w}$ autonomię jednostki bez dostatecznego uzasadnienia.

Próbując zidentyfikować iunctim między interwencją państwa w gospodarkę i nadmiernym rozbudowaniem regulacji prawnokarnych, należałoby wskazać na wielokrotnie już wspomniany paternalizm państwa, który z perspektywy indywidualistycznej należałoby uznać za nieuzasadniony, a wręcz niedopuszczalny. Nie porzucając tej optyki, można by również argumentować, że jest on moralnym złem, ponieważ odbiera jednostkom prawo do kontrolowania własnych dóbr, a w ujęciu skrajnym może rodzić obawę o wygaszenie zdolności człowieka do formułowania racjonalnego osądu i podejmowania samodzielnych decyzji ${ }^{36}$. Skoro zaś sankcja karna, polegająca na pozbawieniu jednostki wolności, mienia, odebraniu prawa do wykonywania zawodu itp., sama w sobie jest złem, to jej zastosowanie wiązać się musi z zabezpieczeniem realnych dóbr w przyszłości ${ }^{37}$. Celem prawa nie może być zaś siłowe wdrażanie w życie nauki o moralności.

\section{Bibliografia}

Banasik K., W kwestii penalizacji kazirodztwa, „Prokuratura i Prawo” 2011, nr 4.

Budyn M., Kryminalizacja eutanazji, posiadania narkotyków oraz eksploatacji prostytucji - przejawy usprawiedliwionego paternalizmu państwa?, „Annales Universitatis Mariae Curie-Skłodowska - Sectio G” 49, 2002.

Budyn-Kulik M., Prawnokarna problematyka kazirodztwa w ujęciu paternalistycznym, „Wojskowy Przegląd Prawniczy" 2012, nr 1-2.

Czepita S., Czesława Znamierowskiego koncepcja „redukcji indywidualizującej”, „Ruch Prawniczy, Ekonomiczny i Socjologiczny" 1987, nr 3.

Derek M., Nakłanianie do rezygnacji z oszczędzania w pracowniczych planach kapitatowych analiza karnoprawna, „Palestra” 2018, nr 12.

Derlatka M., Konstytucyjność kryminalizacji posiadania narkotyków, „Prokuratura i Prawo” 2010, nr $7-8$.

Falandysz L., O koncepcji tzw. „przestęstw bez ofiar”, „Państwo i Prawo” 1978, nr 7-8.

Giezek J., Kolizja dóbr a prawnokarna ochrona wolności, [w:] Prawnokarne aspekty wolności. Materiaty z konferencji, Arłamów, 16-18 maja 2005 r., red. M. Mozgawa, Kraków 2006.

Gruszecka D., Ochrona dobra prawnego na przedpolu jego naruszenia. Analiza karnistyczna, Warszawa 2012.

Hayek F.A. von, Droga do zniewolenia, przeł. K. Gurba et al., Kraków 2015.

Hayek F.A. von, Prawo, legislacja i wolność, przeł. G. Łuczkiewicz, Warszawa 2020.

${ }^{36}$ M. Budyn, Kryminalizacja..., s. 127.

37 A. Zoll, Prawo..., s. 121. 
Kaczmarek T., Recenzja pracy R. Dębskiego: „Pozaustawowe znamiona przestępstwa (O ustawowym charakterze norm prawa karnego i znamionach typu czynu zabronionego nie określonych w ustawie)”, „Państwo i Prawo” 1996, nr 8.

Kodeks karny. Część szczególna. Komentarz, red. J. Giezek, Warszawa 2021.

Kodeks karny. Komentarz, red. R.A. Stefański, Warszawa 2020.

Konarska-Wrzosek V., Przedmiot ochrony przy typie przestęstwa kazirodztwa, [w:] Aktualne problemy prawa karnego. Księga pamiątkowa z okazji jubileuszu 70. urodzin profesora Andrzeja J. Szwarca, red. Ł. Pohl, Poznań 2009.

Klinowski M., Ustawa o przeciwdziałaniu narkomanii a konstytucyjna zasada proporcjonalności, „Prokuratura i Prawo” 2009, nr 2.

Krajewski K., Sens i bezsens prohibicji. Prawo karne wobec narkotyków i narkomanii, Kraków 2001.

Mises L. von, Planowany chaos, przeł. L.S. Kołek, Warszawa 2019.

Muszyńska A., Uwagi na temat uwarunkowań polityki karnej realizowanej przez sądy na przykładzie stosowania art. 178 a $\$ 2$ k.k. $i$ art. 62-62a ustawy z 2005 roku o przeciwdziałaniu narkomanii, „Nowa Kodyfikacja Prawa Karnego” 58, 2020.

Nock A.J., Państwo - nasz wróg, przeł. L.S. Kołek, Warszawa-Lublin 2017.

Nozick R., Anarchia, państwo i utopia, przeł. P. Maciejko, M. Szczubiałka, Warszawa 2010.

Rothbard M.N., Manifest libertariański, przeł. W. Falkowski, Warszawa 2014.

Rothbard M.N., Rzadowe ,ubezpieczenie” medyczne, [w:] Ekonomiczny punkt widzenia, przeł. J. Lewiński, M. Zieliński, Wrocław 2015.

Tarapata S., Dobro prawne w strukturze przestepstwa. Analiza teoretyczna i dogmatyczna, Warszawa 2016.

Thoreau H.D., O obywatelskim niepostuszeństwie, przeł. M. Barski, Warszawa 2020.

Zoll A., Karalność i karygodność jako odrębne elementy struktury przestępstwa, [w:] Teoretyczne problemy odpowiedzialności karnej w polskim oraz niemieckim prawie karnym, red. T. Kaczmarek, Wrocław 1990.

Zoll A., Ochrona prywatności w prawie karnym, „Czasopismo Prawa Karnego i Nauk Penalnych” $2000, \mathrm{nr} 1$.

Zoll A., O normie prawnej z punktu widzenia prawa karnego, „Krakowskie Studia Prawnicze” $1990, \mathrm{nr} 23$.

Zoll A., Prawo karne w systemie totalitarnym, „Znak” 1992, nr 11.

Studia nad Autorytaryzmem i Totalitaryzmem 43, nr 1, 2021

(C) for this edition by CNS 